\title{
Erupción papulonecrótica de evolución aguda
}

\author{
Molinero Barranco MA. ${ }^{1}$
}

Sanid. mil. 2012; 68 (1): 59-60; ISSN: 1887-8571

Mujer de 66 años de edad, con antecedentes personales de dos abortos y artrosis en ambas rodillas que acudió a mi consulta por un cuadro consistente en unas ronchas de color rojo que se cubren de una costra. Afectan a todo el cuerpo menos a la cara.

Tras acudir a su médico, éste le prescribe un antihistamínico y un corticoide tópico. No siente mejoría, ya que las lesiones continúan saliendo. A la exploración observo unas lesiones papulosas, de color rojizo y purpúricas, de aspecto liquenoide, algunas de ellas cubiertas por una costra serohemorrágica. Otros elementos muestran una vesiculación y necrosis superficial. Afectan al tronco y a los miembros, respetando las palmas y las

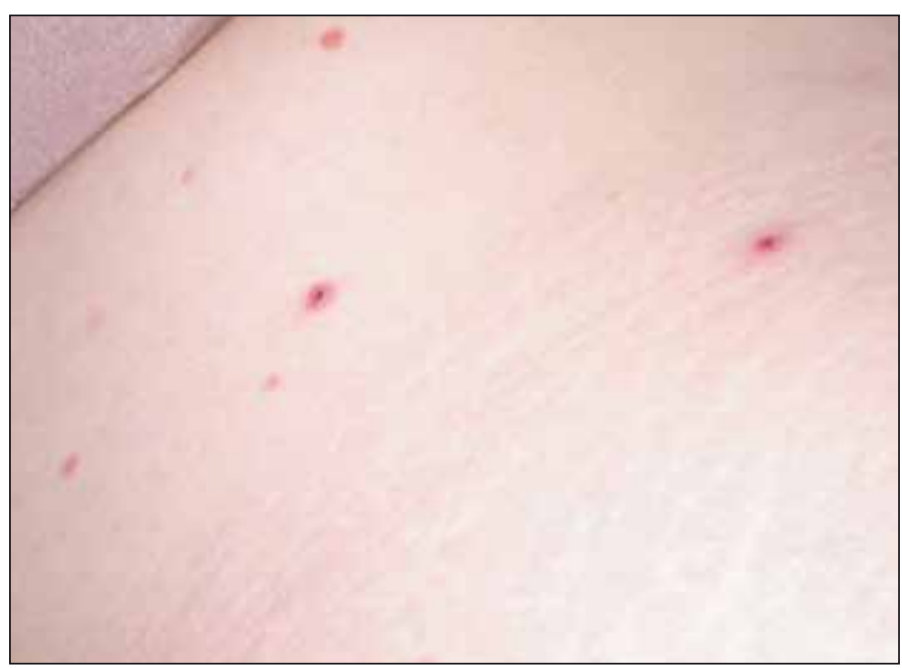

Figura 1. Pápulas liquenoides, purpúricas y necróticas. plantas, así como la cara. Como síntomas subjetivos presenta un ligero prurito. La paciente mantiene el estado general y está afebril.

Realizada una biopsia incisional de una de las lesiones, en el informe histopatológico reza la presencia de necrosis epidérmica, con ulceración e infiltrados linfocitarios perivasculares en la dermis superficial y media. Realiza tratamiento con un comprimido de 30 mg de deflazacort tomado por la mañana hasta le remisión de los brotes, reduciendo la dosis $15 \mathrm{mg}$ cada semana hasta retirar el medicamento del todo, y un comprimido de $25 \mathrm{mg}$ de hidroxicina cada ocho horas mientras haya prurito.

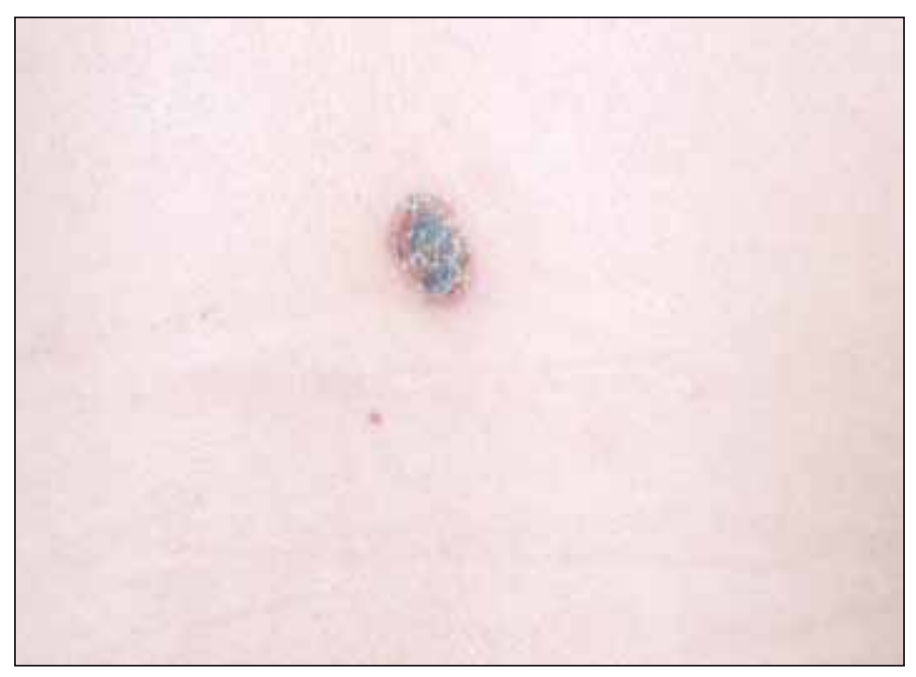

Figura 2. Detalle de una de las lesiones.

${ }^{1}$ Tcol. Médico (Retirado) 


\section{Diagnóstico: Pitiriasis liquenoide varioliforme y aguda o Enfermedad de Mucha-Habermann}

\section{DISCUSIÓN}

Se trata de una dermatosis que se caracteriza por presentar brotes recurrentes de pápulas liquenoides de superficie queratósica, entremezcladas con vesículas y pústulas que se desecan en costra y que dejan una cicatriz varioliforme al curarse. Existe una forma aguda y otra crónica. La primera fue descrita por Mucha en 1916 y posteriormente por Habermann en 1925. La forma crónica fue estudiada y descrita por Juliusberg en $1889^{1}$ Epidemiológicamente afecta a niños con menos de diez años, presentando dos picos de frecuencia, unos a los 5 y otro a los 10 años y a adultos jóvenes, con predominio masculino ${ }^{2}$. Su etiología no es del todo clara, no se sabe con certeza si esta patología se debe a una hipersensibilidad a un agente bacteriano como el estreptococo betahemilítico ${ }^{3}$, parasitario como el toxoplasma o vírico como el virus de Epstein y Barr o el virus de la inmunodeficiencia humana, ya que se han descrito casos tras la infección por estos microorganismos. Otras veces se ha relacionado con una toxicodermia por la presencia de vasculitis leucitoclástica. Clínicamente se caracteriza por la aparición de forma brusca e intensa de elementos maculopapulosos y escamosos, de aspecto purpúrico, alternándose con elementos vesicopustulosos que se necrosan centralmente y se cubren de una serocostra. Suelen dejar una cicatriz varioliforme al curarse. Afectan al tronco y a la raíces de los miembros, así como a los pliegues, donde son más numerosos. Si el cuadro es más intenso puede verse afectada la región palmoplantar, así como el estado general, apareciendo fiebre, artralgias y linfoadenopatías. Evoluciona hacia la curación entre 1 y 6 meses, existiendo posibilidad de recaídas. Degos describió en 1966 la variante que denominó ulceronecrótica hipertérmica con grave afectación del estado general e impetiginización de las lesiones. La forma crónica se caracteriza por la presencia de elementos papuloeritematosos, de $5 \mathrm{~mm}$ de diámetro, con el tiempo se tornan más oscuros y escamosos, pudiéndose desprender la costra con una cucharilla sin causar sangrado (signo de la escama de lacre). Coexisten elementos en distinto estadio.

La lesión se resuelve espontáneamente en 15 días dejando una hiperpigmentación transitoria. La evolución se prolonga durante meses o años. Existe una tercera forma menos frecuente, la pitiriasis liquenoide leucomelanodérmica. Histológicamente la hiperqueratosis paraqueratósica, exocitosis de células mononucleadas, espongiosis e infiltrados linfocitarios perivasculares, junto a una vasculitis leucocitoclástica, en la forma aguda, constituyen los rasgos característicos de la dermatosis.

El diagnóstico diferencial debemos establecerlo con la papulosis linfomatoide que se trata de un linfoma T cutáneo CD30+, psoriasis en gotas, pitiriasis rosada, varicela, liquen plano diseminado, sífilis secundaria, erupciones medicamentosas ${ }^{4}$. Me decanto por el diagnóstico de pitiriasis liquenoide por la forma de presentación, las características clínicas de las lesiones, por el estudio histopatológico y por la evolución de la dermatosis. Se trata de una enfermedad rara y que puede llegar a ser grave pudiéndose llegar al 20\% de mortalidad. Se recomienda, pues, el estricto control de los pacientes porque pueden acabar en unidades de control intensivo.

No existe tratamiento específico. La eritromicina, las tetraciclinas y los corticoides por vía oral, parecen conseguir cierto éxito, así como la fototerapia ${ }^{5}$. En cuadros muy intensos han dado buen resultado dosis bajas de metotrexato ${ }^{6}$.

\section{BIBLIOGRAFÍA}

1. Pérez Pelegay J., Charro Martínez L., Grasa Jordán M.P., Carapeto Márquez De Prado F.J. Pitiriasis liquenoide. Med Cutan Iber Lat Am 2007; 35(4): 167-173.

2. Romaní J., Puig L, I, Fernández-Figueras Mt, De Moragas J.M. Pityriasis lichenoides in children: Clinicopathologic review of 22 patients. Ped Dermatol 1998; 15: $1-6$.

3. Englis J.C., Collins M., Brayant-Bruce C.: Pityriasis lichenoides and varioliforme acuta and group-A Beta haemolytic streptococcal infection. Int J Dermatol 1995; 34: 642-644.

4. Fitzpatricck T.B. Atlas en color y sinopsis de dermatología clínica. $4^{\mathrm{a}}$ ed. McGraw-Hill Interamericana. Madrid 2001; 134.

5. Tay Y.K., Morrelli J.G., Westo W.L. Experience with UVB phototherapy in children. Pediatr Dermatol 1996; 13: 106-409.

6. Lazaridou E, Fotiadou C, Tsorova C, Trachana M, Trigoni A, Patsatsi A, Ioannides D. Resistant pityriasis lichenoides et varioliformis acuta in a 3-year-old boy: successful treatment with methotrexate. Int J Dermatol. 2010 Feb; 49(2):215-7. 